\title{
Laporan Kasus: Petekie pada Rongga Mulut Akibat Faktor latrogenik pada Pasien Anak
}

\author{
(Case Report: Petechiae in The Oral Cavity Due to latrogenic Factors in Pediatric Patients)
}

Helmi Hirawan', Fanni Kusuma Djati', Eliska Reza Mulitasari²

1 Departemen Ilmu Penyakit Mulut, Jurusan Kedokteran Gigi, Fakultas Kedokteran, Universitas Jenderal Soedirman

2 Jurusan Kedokteran Gigi, Fakultas Kedokteran, Universitas Jenderal Soedirman

\begin{abstract}
Abstrak
Petekie merupakan lesi merah yang berbentuk bulat dengan ukuran diameter kurang dari 2 mm yang terletak pada jaringan subkutan atau submukosa. Lokasi yang sering terjadi yaitu pada mukosa bukal, pipi, bibir, lateral lidah, dasar lidah, palatum, orofaringeal. Faktor etiologi dari petekie terdiri dari dua jenis yaitu faktor lokal dan faktor sistemik. Faktor lokal yang menyebabkan petekie seperti trauma, cedera, fellatio, trauma iatrogenik. Faktor sistemik yang menyebabkan petekie seperti keabnormalan platelet, gangguan faktor pembekuan darah, kerusakan pembuluh darah. Seorang perempuan berumur 8 tahun bersama orang tua datang ke RSGMP Unsoed dengan keluhan terdapat bintik berwarna merah pada dasar mulut, pasien tidak menyadari adanya kemerahan di bawah lidah sebelum dilakukan perawatan pada gigi bawah sebelah kanan, tidak merasakan sakit dan tidak merasakan terganggu dengan kondisi tersebut, pasien mengaku belum pernah terjadi hal tersebut. Pasien sedang dalam perawatan gigi pulpotomi. Petekie yang disebabkan karena traumatik dapat sembuh dengan menghilangkan faktor etiologi.
\end{abstract}

Kata kunci: faktor iatrogenik, lesi merah, petekie

\section{Abstract}

Petechiae are round red lesions with a diameter of less than $2 \mathrm{~mm}$ located in the subcutaneous tissue or submucosa. Locations that often occur are the buccal mucosa, cheeks, lips, lateral tongue, base of the tongue, palate, oropharynx. The etiologic factors of petechiae consist of two types, local factors and systemic factors. Local factors that cause petechiae such as trauma, injury, fellatio, iatrogenic trauma. Systemic factors that cause petechiae such as platelet abnormalities, blood clotting factor disorders, blood vessel damage. An 8-year-old woman with her parents came to RSGMP Unsoed with complaints of red spots on the floor of the mouth, the patient was not aware of the redness under the tongue before treatment on the right lower tooth, did not feel pain and did not feel disturbed by this condition. The patient stated that this had never happened before. The patient is undergoing dental pulpotomy. Petechiae caused by trauma can heal by eliminating the etiologic factor.

Keywords: iatrogenic factor, petechia, red lession

Korespondensi (Correspondence) : Eliska Reza Mulitasari. Kedokteran Gigi, Fakultas Kedokteran, Universitas Jenderal Soedirman.. Jl. Dr.Suparno - Purwokerto, 53i22. Email: ms.eliska@yahoo.co.id

Petekie merupakan lesi merah yang berbentuk bulat dengan ukuran diameter kurang dari 1-2 mm yang terletak pada jaringan subkutan atau submukosa. Petekie dapat terjadi pada semua usia baik laki-laki maupun perempuan. Lokasi yang sering terjadi yaitu pada mukosa bukal, pipi, bibir, lateral lidah, dasar lidah, palatum, dan orofaringeal. ${ }^{1,3}$

Faktor etiologi dari petekie terdiri dari dua jenis yaitu faktor lokal dan faktor sistemik. Faktor lokal terdiri trauma (menggigit benda tajam, benda asing), cedera, fellatio, trauma iatrogenik. latrogenik merupakan kondisi yang disebabkan oleh perawatan dokter terhadap suatu penyakit atau keadaan pada pasien. Salah satu jenis faktor iatrogenik pada prosedur dental yang menyebabkan terjadinya petekie yaitu penggunaan saliva ejector yang tidak tepat, handpiece, anestesi, penempatan sendok cetak yang tidak tepat.

Faktor sistemik yang dapat menyebabkan terjadinya ptekie yaitu keabnormalan platelet, gangguan faktor pembekuan darah, kerusakan pembuluh darah. ${ }^{1,2}$ Sebagai dokter gigi apabila pada pasien terdapat petekie, yang berhubungan dengan faktor sistemik, segera dirujuk untuk dilakukan pemeriksaan dan perawatan lebih lanjut.1.2 Petekie yang disebabkan karena faktor sistemik biasanya tidak hanya bermanifestasi di dalam rongga mulut, namun disertai adanya petekie di kulit. Petekie yang sering terjadi pada usia anak biasanya disebabkan karena traumatik dan gangguan darah (leukemia, trombositopenia, hemophilia) ${ }^{2,3}$. Tujuan dibuat laporan ini yaitu mengetahui petekie pada rongga mulut dan etiologi yang menyertai pada pasien anak.

\section{LOPORAN KASUS}

Seorang perempuan berumur 8 tahun bersama orang tua datang ke RSGMP Unsoed dengan keluhan terdapat bintik benwarna merah pada dasar mulut, pasien tidak menyadari adanya kemerahan di bawah lidah sebelum dilakukan perawatan pada gigi bawah sebelah kanan, tidak merasakan sakit dan tidak merasakan terganggu dengan kondisi tersebut, pasien mengaku belum pernah terjadi hal tersebut. Pasien sedang dalam perawatan gigi pulpotomi.

Pemeriksaan umum dalam batas normal. kesadaran compos mentis, respirasi 15 
kali per menit, nadi 60 kali per menit dan suhu $37 \circ$ C. Pemeriksaan ekstraoral menunjukkan tidak ada kelainan pada wajah, mata, leher, dan ekstremitas. Kelenjar getah bening di servikal tidak ditemukan adanya pembesaran. Pemeriksaan intraoral menunjukkan adanya lesi berupa petekie, berwarna merah berjumlah 7 , berukuran $1 \times 1 \mathrm{~mm} ; 1 \times 0,5 \mathrm{~mm} ; 1 \times 1 \mathrm{~mm} ; 0,5 \times 1 \mathrm{~mm} ; 1 \times 0,5 \mathrm{~mm}$; $1 \times 1 \mathrm{~mm} ; 1 \times 1 \mathrm{~mm}$, konsistensi lunak pada dasar mulut (gambar 1). Ketika dilakukan penekanan pada lesi tidak berubah pucat dan tetap berwarna merah. Berdasarkan anamnesa dan pemeriksaan klinis diagnosis dari pasien tersebut yaitu other and unspecified lesion pada mukosa oral berupa lesi petekie (Kode ICD 10= K137).

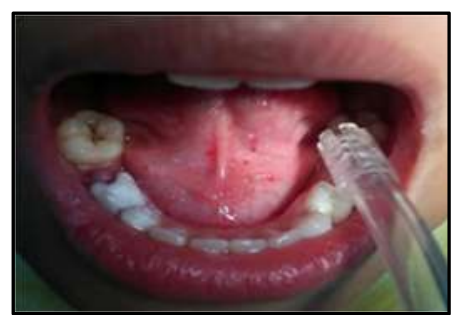

Gambar 1. Gambaran klinis pada pasien kunjungan pertama

Diagnosa banding yaitu hemangioma kapileri. Penatalaksanaan kasus tersebut yaitu, Dental health education, diedukasi agar tidak memainkan lidah pada area dasar mulut, menjaga kebersihan rongga mulut, mengkonsumsi makanan yang bergizi dan kontrol 1 minggu. Menjelaskan kepada orang tua pasien dan pasien bahwa hal tersebut bukan keganasan, bintik merah muncul disebabkan karena alat meyedot saliva ketika perawatan pulpotomi.

Satu minggu kemudian pasien datang kembali untuk kontrol. Pemeriksaan umum dalam batas normal. kesadaran compos mentis, respirasi 16 kali per menit, nadi 63 kali per menit dan suhu $37 \circ \mathrm{C}$. Pemeriksaan intraoral menunjukkan sudah terjadi penyembuhan lesi, ditandai dengan menghilangnya lesi. Pasien diedukasi untuk tetap menjaga kebersihan rongga mulut, tidak memainkan daerah bawah lidah, mengkonsumsi makan yang bergizi (Gambar 2).

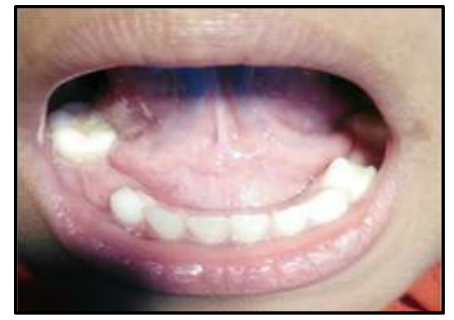

Gambar 2. Keadaan lesi pada hari ke-7 setelah kunjungan

PEMBAHASAN
Lesi merah yang berhubungan dengan keabnormalan pembuluh darah dan darah terdiri dari ptekie, purpura, ekimosis dan hemangioma. Karakteriktik yang membedakan antara petekie, purpura, ekimosis, hematoma yaitu berdasarkan ukuran, bentuk dan lokasi. Petekie merupakan bercak berbentuk bulat, dengan ukuran diameternya 1-2 mm dan berwarna merah, lokasi yang sering terjadi yaitu pada mukosa bukal, pipi, bibir, lateral lidah, dasar lidah, palatum, orofaringeal. Purpura mempunyai ukuran lebih besar dari petekiae, ukurannya diameternya kurang dari $1 \mathrm{~cm}$, berbatas jelas, bentuknya tergantung lokasi jaringan dan jumlah atau pengeluaran darah yang dikumpulkan. Ekimosasisis daerah ekstravasasi darah dengan diameter lebih dari $1 \mathrm{~cm}$, warnanya bervariasi dari merah-ungu (gambar 3). Hematoma merupakan kumpulan ekstravasasi darah yang besar yang berasal dari trauma yang menimbulkan masa teraba. di rongga mulut sebagai akibat benturan pada wajah, erupsi gigi atau kerusakan dari vena alveolaris superior posterior akibat pemberian anestesi. Warnanya coklat-merah tua, nyeri jika diraba (gambar 4). 4.5

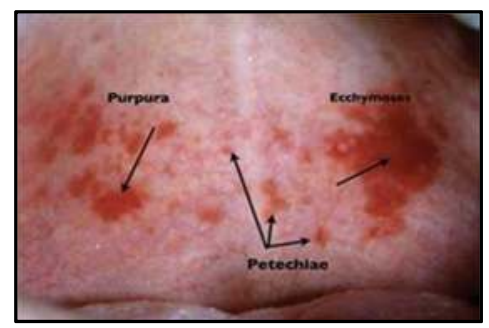

Gambar 3. Gambaran klinis lesi merah berupa petekie, purpura, dan ekimosis.

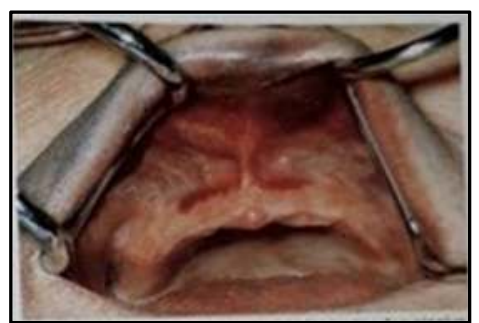

Gambar 4. Gambran klinis lesi merah berupa hematoma pada mukosa rahang atas dan gingiva

Penyebab terjadinya petekie dapat di golongkan menjadi beberapa kategori yaitu: ${ }^{6}$ 1. Infeksi trauma

a. Virus: Enteroviru, Parvovirus B19, Dengue

b. Bakteri:Meningococcal, Scarlet fever, Infective endocarditis.

c. Rikettsial:Rocky Mountain potted Fever

2. Trauma

a. Trauma karena mengigit benda tajam, benda asing

b. Trauma iatrogenik

c. Peningkatan tekanan, setelah batuk, muntah dan mengejan. 
3. Gangguan pada darah dan maligna Leukemia, Idiopathic thrombocytopenic purpura (ITP), anemia, Diseminated Intravascular Coagulation (DIC), Splenomegaly, Haemolytic Uraemic Syndrome (HUS), Neonatal Alloimmune Thrombocytopenia

4. Vaskulitis dan kondisi inflamasi, Henoch schonlein purpura (HSP), Systemic Lupus Erythematous

5. Gangguan pada jaringan konektif, seperti Ehlens Danlos

6. Kongenital,
a. Wiscott Aldrich,
b. Glanzmann Thrombasthenia,
c. Bernard Soulier

7. Lain-lain.

Reaksi obat, defisiensi vitamin K, liver kronik.

Petekie terjadi akibat adanya perdarahan di dalam lapisan dermis. Penyebab patofisiologi utama petekie yaitu trombositopenia, disfungsi trombosit, gangguan koagulasi dan hilangnya integritas pembuluh darah sehingga menimbulkan lesi berupa petekie.3.5 Penentuan diagnosis petekie didasarkan pada anamnesa secara lengkap, mengetahui penyebab petekie, ciriciri utama yaitu mengetahui waktu terjadi lesi, pola anatomi, lokasi dan sumber perdarahan, kronologis serta didukung gejala lain seperti demam, batuk, muntah dan gastroenteritis. Selain intraoral pada ektraoral dilakukan pemeriksaan secara menyeluruh dari kepala hingga kaki, bisa dimungkinkan adanya petekie pada ekstraoral. Apabila dicurigai petekie karena sistemik, maka dilakukan pemeriksaan penunjang pemeriksaan jumlah trombosit, jumlah sel darah putih.2,6

Penentuan diagnosis banding pada kasus petekiae lebih tepat menggunakan pemeriksaan penunjang dengan biopsi, dan etiologi yang menyertai dimasukkan dalam diagnosis banding. Macam-macam diagnosa banding untuk kasus ptekie yaitu amalgam tato, nevus biru, hemangioma, malformasi pembuluh darah, diskrasia darah, kerusakan sumsum tulang seperti myeloma.7,8 Perawatan yang dapat dilakukan pada kasus petekie dikategorikan berdasarkan jenis etiologi, keganaan atau tidak. Pada pasien yang tidak disertai dengan gejala sistemik maka tidak diperlukan perawatan khusus, hanya dilakukan dengan menghilangkan sumber penyebab petekie. Pada pasien yang di diagnosa disertai dengan kondisi sistemik maka diperlukan suatu evaluasi khusus dan diberikan antibiotik intravena. $2,9,10$

Petekie merupakan bercak berbentuk bulat, dengan ukuran diameternya 1-2 mm dan berwarna merah, lokasi yang sering terjadi yaitu pada mukosa bukal, pipi, bibir, lateral lidah, dasar lidah, palatum, orofaringeal. Penyebab petekie terdiri dari dua faktor yaitu faktor lokal dan faktor sistemik. Petekie yang disebabkan faktor sistemik tidak hanya bermanifestasi pada mukosa oral namun dapat muncul pada bagian kulit. Petekie dapat terjadi pada semua umur baik laki-laki maupun perempuan. Perawatan yang diberikan yaitu dengan menghilangkan faktor etiologi, pemberian antibiotik intravena untuk petekie yang disebabkan karena faktor sistemik.

\section{DAFTAR PUSTAKA}

1. Regezi JA, Sciubba JJ, Jordan RCK. Oral Pathology Clinical Corelation, Elsevier, China. 2018.

2. Delong L, Burkhart W. General And Oral Pathology For The Dental Hygienist, Wolters Kluwer, Lippincott William and Wilkins. 2008.

3. Tarakji B, Umair A., Durga P., Alsakran M. Diagnosis of Oral Pigmentations and Maligna Transformations, Singapore Dental Journal, 2014; 35: 39-46.

4. Langlais RP., Miller CS., Gehrig JN, Atlas Berwarna Lesi Mulut Yang erring ditemukan, EGC, Jakarta. 2015

5. Djati, F. K., \& Dewi, C. K. Laporan Kasus: Tatalaksana Hematoma Akibat Trauma. STOMATOGNATIC-Jurnal Kedokteran Gigi 2018; 15(2): 26-29.

6. Mc Grath A, Barrett MJ. Petchiae, StarPeals Publisshing LCC. 2018.

7. Koray, M., \& Tosun, T. Oral mucosal trauma and injuries. In Trauma in Dentistry. IntechOpen. 2019

8. Alawi, F. Pigmented lesions of the oral cavity: an update. Dental Clinics of North America 2013; 57(4): 699.

9. Jin, L. J., Lamster, I. B., Greenspan, J. S., Pitts, N. B., Scully, C., \& Warnakulasuriya, S. Global burden of oral diseases: emerging concepts, management and interplay with systemic health. Oral diseases 2016; 22 (7): 609-619.

10. Mays, J. W., Sarmadi, M., \& Moutsopoulos, N. M. Oral manifestations of systemic autoimmune and inflammatory diseases: diagnosis and clinical management. Journal of Evidence Based Dental Practice 2012; 12 (3): 265-282. 